\title{
SKP2 wt Allele
}

National Cancer Institute

\section{Source}

National Cancer Institute. SKP2 wt Allele. NCI Thesaurus. Code C49541.

Human SKP2 wild-type allele is located within 5p13 and is approximately $32 \mathrm{~kb}$ in length. This allele, which encodes S-phase kinase-associated protein 2 , is involved in cell cycle arrest at the G1/S transition of the cell cycle. SKP2 variant alleles have been established as alleles that are causally involved in the pathogenesis of lymphomas. 